\title{
Correction to: Genomic Action of Sigma-1 Receptor Chaperone Relates to Neuropathic Pain
}

\author{
Shao-Ming Wang ${ }^{1} \cdot$ Nino Goguadze ${ }^{1} \cdot$ Yuriko Kimura ${ }^{1} \cdot$ Yuko Yasui ${ }^{1} \cdot$ Bin Pan $^{2} \cdot$ Tzu-Yun Wang ${ }^{1,3} \cdot$ Yoki Nakamura ${ }^{1,4}$. \\ Yu-Ting Lin ${ }^{1} \cdot$ Quinn H. Hogan ${ }^{2} \cdot$ Katherine L. Wilson ${ }^{5} \cdot$ Tsung-Ping Su $^{1}$ (D) $\cdot$ Hsiang-en Wu ${ }^{1}$
}

Published online: 1 February 2021

(C) The Author(s) 2022

\section{Correction to: Mol Neurobiol https://doi.org/10.1007/s12035-020-02276-8}

The original version of this article unfortunately contained some mistakes. The current Electronic Supplementary file is not correct and should be updated.

The original paper has been corrected.

Publisher's Note Springer Nature remains neutral with regard to jurisdictional claims in published maps and institutional affiliations.
Open Access This article is licensed under a Creative Commons Attribution 4.0 International License, which permits use, sharing, adaptation, distribution and reproduction in any medium or format, as long as you give appropriate credit to the original author(s) and the source, provide a link to the Creative Commons licence, and indicate if changes were made. The images or other third party material in this article are included in the article's Creative Commons licence, unless indicated otherwise in a credit line to the material. If material is not included in the article's Creative Commons licence and your intended use is not permitted by statutory regulation or exceeds the permitted use, you will need to obtain permission directly from the copyright holder. To view a copy of this licence, visit http://creativecommons.org/licenses/by/4.0/.

The online version of the original article can be found at https://doi.org/ $10.1007 / \mathrm{s} 12035-020-02276-8$

Tsung-Ping Su

TSU@ intra.nida.nih.gov

1 Cellular Pathobiology Section, Integrative Neuroscience Research Branch, Intramural Research Program, National Institute on Drug Abuse, NIH/DHHS, Suite 3512, 333 Cassell Drive,

Baltimore, MD 21224, USA

2 Department of Anesthesiology, Medical College of Wisconsin, Milwaukee, WI 53226, USA

3 Department of Psychiatry, College of Medicine, National Cheng Kung University, Tainan City 70101, Taiwan

4 Department of Pharmacology, Graduate School of Biomedical \& Health Science, Hiroshima University, Hiroshima 734-8553, Japan

5 Department of Cell Biology, Johns Hopkins University School of Medicine, Baltimore, MD 21205, USA 